\title{
OBSADA BISKUPSTW KATOLICKICH OBRZĄDKU ŁACIŃSKIEGO NA ZIEMIACH POLSKICH W LATACH 1795-1918
}

Rozbiory Polski w latach $1772-1793-1795$ i podzial jej terytorium między prawosławną Rosję ( $462000 \mathrm{~km}^{2}$ i 5400000 ludności), protestanckie Prusy (141 400 km² i 2780000 ludności) i józefińską Austrię (130 100 km² i 4150000 ludności) wpłynęły bezpośrednio na załamanie się dawnej, przedrozbiorowej struktury organizacyjnej Kościoła łacińskiego na ziemiach polskich. Jeszcze większe zmiany strukturalne Kościoła polskiego nastąpiły po kongresie wiedeńskim (1815), na którym dokonano nowego podziału ziem polskich. Utworzone wówczas tak zwane Królestwo Polskie z części ziem zaboru pruskiego i austriackiego zostało podporządkowane Rosji, która po krwawym stłumieniu dwóch powstań narodowych $(1830,1863)$ zniosła wszelką jego autonomię i jako Kraj Przywiślański inkorporowała je do Cesarstwa Rosyjskiego.

W ślad za zniszczeniem terytorialnej organizacji dawnej Rzeczypospolitej władze zaborcze przystąpiły w dalszych latach do niszczenia ustroju Kościoła polskiego. To prawda, że struktury organizacyjne Kościoła katolickiego w Polsce, powstałe jeszcze w średniowieczu, wymagały unowocześnienia i reorganizacji, ale motywy, którymi kierowali się zaborcy przy dokonywaniu tych zmian nie płynęły z przyczyn duszpasterskich, ale z ich politycznej racji stanu. W celu zatarcia więc śladów dawnej Rzeczypospolitej tworzono nowe metropolie i diecezje bez dawnej tradycji, szereg natomiast diecezji z czasów polskich zostało zniesionych.

Szereg innowacji zaborczych, przeprowadzonych samowolnie, nie doczekało się nigdy sankcji kanonicznych ze strony Stolicy Apostolskiej. Do tych należała zniesiona przez rząd pruski instytucja prymasostwa polskiego, która w okresie przedrozbiorowym jednoczyła pod względem kościelnym cały Kościół polski. Już tu należy zaznaczyć, że władze zaborcze nie wypracowały wspólnej polityki w stosunku do ustroju metropolitalnego Kościoła polskiego. Mimo pewnych zasad, przyjętych w konwencji petersburskiej (1797), Rosja dążyła do skupienia możliwie największej władzy kościelnej w rękach powołanego do życia w 1783 r. metropolity mohylowskiego („papież rosyjski”). W pierwszym dwudziestoleciu istnienia (1818-1838) faworyzowano również nowego metropolitę warszawskiego, ale od 1839 r. polityka carów w stosunku do Warszawy zmieniła się zupełnie, a nawet pojawiły się projekty likwidacji tej 
metropolii i podporządkowanie jej mohylowskiej prowincji kościelnej.

Austria poza zwiększeniem uprawnień honorowych dla metropolity lwowskiego ob. łac. nie zabiegała o rozszerzenie jego kościelnych prerogatyw, gdyż te nie mieściły się w koncepcji józefińskiego ustroju Kościoła. Krańcowo różną postawę przyjęły Prusy wobec metropolii gnieźnieńskiej. Zmierzała ona całkowicie do obcięcia jej dawnych prerogatyw prymasowskich i metropolitalnych, powtarzały się zakusy całkowitej jej likwidacji, a wreszcie połączono ją unią personalną z Poznaniem, by przenieść ośrodek ciężkości życia kościelnego z tradycyjnie polskiego Gniezna do nowego ośrodka metropolitalnego w Poznaniu ${ }^{1}$.

\section{Zabór rosyjski}

Po tych uwagach wstępnych przypatrzmy się szczegółowo problemowi obsady biskupstw katolickich na ziemiach polskich na wschód od biegu rzek Zbrucza, Bugu, Niemna, inkorporowanych w latach 1772/95 do Cesarstwa Rosyjskiego. Po przejściowej kasacie wszystkich biskupstw katolickich przez carową Katarzynę II z wyjątkiem archidiecezji mohylowskiej i diecezji żmudzkiej (1796), w 1798 r. pod przemożnym wpływem Rosji zniesiono 3 staropolskie biskupstwa ob. łac. w Smoleńsku, Kijowie i Inflantach, a utworzono 2 nowe w Mińsku na Białorusi i w Żytomierzu na Ukrainie. Tak hierarchia Kościoła katolickiego na dawnych ziemiach polskich w Cesarstwie Rosyjskim składała się z arcybiskupstwa - metropolii w Mohylowie i diecezji w: Wilnie, Żmudzi, Mińsku, Kamieńcu Podolskim i połączonych unią personalną w Łucku i Żytomierzu. Do tych 6 diecezji doszła w 1848 r. diecezja tyraspolska z rezydencją w Saratowie nad Donem dla południowych obszarów Rosji. W ramach represji po stłumionym powstaniu styczniowym car Aleksander II zniósł samowolnie diecezję w Kamieńcu Podolskim (1866) i Mińsku na Białorusi $(1869)^{2}$.

Prawo nominacji na wszystkie biskupstwa katolickie w Cesarstwie Rosyjskim przysługiwało faktycznie carowi. Początkowo nominacji tych dokonywali carowie na podstawie faktów dokonanych, które Rzym tolerował (1783). Podstawowe dokumenty papieskie dla tych terenów, a więc bulla Onerosa pastoralis officii cura z 14 IV 1783 r., oraz bulla Maximis undique pressi z 17 XI 1798 r. pomijały to zagadnienie milczeniem ${ }^{3}$, a właściwie tolerowały przyjętą przez carów praktykę. Dopiero konkordat rosyjski z 1847 r. sprawy nominacji biskupów uporządkował w ten sposób, że „naznaczenie biskupów na diecezje i suf-

${ }^{1}$ B. Ku mor, Ustrój i organizacja Kościota polskiego $w$ okresie niewoli narodowej 17721918, Kraków 1980, s. 5-6.

2 Tamże, s. $191 \mathrm{nn}$.

${ }^{3}$ Akty i gramoty o ustroistwie i uprawlenij Rimsko-katoliczeskoj Cerkwi w Imperij Rossijskoi i Carstwe polskom, Petersburg 1849, s. 6-13, 124-133. 
raganie w Cesarstwie Rosyjskim i w Królestwie Polskim będzie miało miejsce zawsze według uprzedniego porozumienia się między cesarzem a Stolicą Swiętą. Instytucja kanoniczna będzie im udzielana przez Jego Swiątobliwość w zwyklym porządku" (par. 12) ${ }^{4}$.

Car rosyjski, korzystając $\mathrm{z}$ tych prerogatyw, prowadził trójaspektową politykę w stosunku do obsady biskupstw katolickich w Rosji. $\mathrm{Z}$ reguły mianował on na te urzędy ludzi lojalnych, na których mógł liczyć, że będą mu ulegli, w pewnych wypadkach bardzo chwiejnych w sprawie narodowej, a nawet nie zawsze wiernym zasadom Kościoła. Zdarzały się wypadki, że Stolica Apostolska nie potwierdzała nominatów carskich (1841). Nominaci carscy byli najczęściej ludźmi starymi, podatnymi na wszelkie intrygi i manipulacje rządowe i często zastraszeni perspektywą deportacji na Syberię. Załączona niżej tabela nr 1 przedstawia ten problem dla lat $1798-1900^{5}$.

Tab. 1: Wiek nominatów na biskupstwa w metropolii mohylowskiej

\begin{tabular}{|l|l|rrrrr|c|}
\hline \multirow{2}{*}{ Lp. } & Nazwa diecezji & \multicolumn{5}{|c|}{ Do roku życia } & Razem \\
& & 50. & 60. & 70. & 75. & 80. & \\
\hline 1. & Mohylów & 1 & 1 & 4 & 2 & 1 & 9 \\
2. & Kamieniec Podolski & 1 & - & 3 & 1 & $(1866$ zniesiona $)$ & 5 \\
3. & Łuck-Żytomierz & 1 & 3 & - & 1 & - & 5 \\
4. & Mińsk & 1 & 2 & $(1869$ zniesiona $)$ & 3 \\
5. & Tyraspol & 3 & - & - & 1 & - & 4 \\
6. & Wilno & 3 & 1 & 1 & 1 & - & 6 \\
7. & Żmudź & 2 & 2 & - & - & - & 4 \\
\hline Łącznie & 12 & 9 & 8 & 6 & 1 & 36 \\
\hline
\end{tabular}

Tylko 33,33\% nominatów na stolice biskupie w tej części ziem polskich liczyło do 50 lat w chwili prekonizacji papieskiej. Dalszych $25 \%$ nominatów liczyła do 60 lat, $22,22 \%$ do 70 lat i 16,67\% do 75 lat; jeden z nominatów (K. Cieciszowski) przekroczył w chwili nominacji na metropolitę mohylowskiego 83 lata. Szczególnie poważny wiek w chwili nominacji mieli metropolici mohylowscy, którzy skupili w swoich rękach ważny zakres władzy kościelnej i odgrywali większą rolę w dziejach Kościoła polskiego w Rosji. Tylko 2 z nich miało mniej niż 60 lat, pozostałych 7 liczyło przeszło 60 lat.

Nominaci byli z reguły narodowości polskiej, a tylko biskupi żmudzcy byli

${ }^{4}$ S. Ols za mows k a - S k ow rońs k a, Le concordat de 1847 avec la Russie d'après les documents authentiques, „Sacrum Poloniae Millenium” \&-9: $1967 \mathrm{nr} 87$ s. 793 (§ 12).

${ }^{5}$ R. Ritzle r, P. S e f r in, Hierarchia catholica medii et recentioris aevii, vol. $6(1730-1799)$, Patavii 1958, s. 142, 266, 291, 293, 365, 442; vol. 7 (1800-1846), Patavii 1968, s. 129, 244, 266, 268, 332, 396; vol. 8 (1846-1903), Patavii 1979, s. 175, 350 n., 387, 407, 498, 556, 591. 
Litwinami. Nominaci zbyt lojalni wobec zaborcy rosyjskiego byli zgorszeniem dla wiernych, a w pewnych wypadkach kandydatury takie odrzucała Stolica Apostolska. Tak było zwłaszcza po stłumieniu powstania listopadowego, kiedy wysunięte przez cara Mikołaja I kandydatury (1843) zostały odrzucone, jako że mogły przynieść dla życia religijnego więcej zła, niż dobra ${ }^{6}$. Toteż pap. Grzegorz XVI oświadczył w tym względzie carowi Mikołajowi I w dniu 16 VIII 1843 r., że „Rzymskiemu biskupowi przysługuje po wsze czasy niepodzielne prawo wyrokowania o kwalifikacjach mianowanych osobistości, oraz moc ich odrzucania, jak to rzeczywiście ma miejsce, ilekroć w swym sumieniu nie uważa ich za godnych tej godności..., a jeśli Nasze święte obowiązki zmusiły Nas czasem do wykluczenia niektórych kandydatów, których Wasza Cesarska Mość poleciła, uczyniliśmy to jedynie po najbardziej drobiazgowym badaniu, oraz otrzymaniu z najbardziej pewnych źródeł ujemnych informacji"7.

$\mathrm{Na}$ tym tle dochodziło do długich i przewlekających się konfliktów między autokratycznymi władcami Rosji a Stolicą Apostolską. „Wasza Swiątobliwość — pisał 11 VII 1843 r. car Mikołaj I do pap. Grzegorza XVI — nie może nie zrozumieć mych słów. Jestem suwerennym władcą, jako taki jestem namiestnikiem Waszej Swiątobliwości do spraw wyznania rzymskiego w krajach, które Bóg mi powierzył. Zechciej tedy, Ojcze święty, ułatwić mi wypełnienie mej powinności”. W zakończeniu tegoż listu car rosyjski pisał: „Jeśliby się spodobało Waszej Swiątobliwości cofnąć swoją decyzję i odmowę i zatwierdzić biskupów, których przedłożyłem, jeśliby się zgodzila na takie rozgraniczenie diecezji, o jakie prosiłem i jeśliby Wasza Świątobliwość raczyła udzielić swego błogosławieństwa Akademii Duchownej, którą tutaj założyłem..., wówczas wyznanie rzymskie podniesie się do tego poziomu, na jakim stać powinno"8. Ten carski „poziom wyznania rzymskiego” miał papież okupić likwidacją metropolii warszawskiej i mohylowskiej i utworzeniem jednej metropolii dla diecezji Cesarstwa Rosyjskiego i Królestwa Polskiego w Wilnie, zatwierdzeniem likwidacji Uniwersytetu i Wydziału Teologicznego w Wilnie i stworzenie na obcym gruncie narodowym i wyznaniowym Akademii Duchownej w Petersburgu, oraz nominacją na biskupów 6 skompromitowanych narodowo i kościelnie kandydatów. Taka sytuacja powtórzyła się również w latach późniejszych XIX wieku. Car rosyjski zabiegał również o uzyskanie prawa nominacji biskupów w utworzonym w 1815 r. Królestwie Polskim. Już w Zasadach konstytucji Królestwa Polskiego, ogłoszonych przez cara Aleksandra I w dniu 25 V 1815 r., zajęto się niejasno tą sprawą, a konstytucja nadana przez cara

\footnotetext{
${ }^{6}$ A. B ou dou, Stolica Święta a Rosja, tłum. Z. Sk ow roń s k a, t. 1. Kraków 1928, s. 369 nn.

${ }^{7} \mathrm{~S}$. Olszamowska-Skow rońs ka, La correspondance des papes et des empereures de Russie (1814-1878) selon les domunents authentiques, Roma 1970, $\mathrm{nr} 55$ s. 259-262.

${ }^{8}$ Tamże, nr 52 s. $256-258$.
} 
27 XI 1815 r. stanowiła, że „król mianuje arcybiskupów i biskupów różnych wyznań, sufraganów, prałatów i kanoników"9.

To jednostronne postanowienie konstytucji było trudniejsze do przyjęcia przez Stolicę Apostolską. Król bowiem polski, którym odtąd miał być każdorazowy car rosyjski, był wyznania prawosławnego, podczas gdy król polski okresu przedrozbiorowego był katolikiem. Dlatego też sprawa ta stała się przedmiotem rokowań ze Stolicą Apostolską w latach 1816-1818. Sprawę tę poruszył również w liście apostolskim Pius VII z 22 XI 1817 r. Intimement convaineus, skierowanym do cara Aleksandra I w związku z nominacją 3 biskupów przez cara rosyjskiego. Pisał w nim papież, że przyjęcie zasady nominacji biskupów katolickich przez cara „równałoby się usankcjonowaniu zasad i poglądów najzupełniej sprzecznych z zasadami i poglądami religii katolickiej, byłoby to podważeniem podstaw konstytucji Kościoła katolickiego". W dalszych słowach listu papież zaprzeczył, aby jakikolwiek papież kiedykolwiek nadał niekatolickiemu monarsze prawa mianowania biskupów. Nic dziwnego, że $\mathrm{z}$ trzech nominatów carskich papież prekonizował tylko jednego, ks. J. Podhorodeńskiego na biskupa pomocniczego z Żytomierza, którego przeniósł na to samo stanowisko do Łucka (1817). Dwie pozostałe kandydatury: ks. prał. Lipskiego i ks. W. Łabuńskiego zostały odrzucone ${ }^{10}$.

W tej sytuacji mimo faktycznych nominacji carskich na stolice biskupie w Cesarstwie i Królestwie wraz z Krakowem, Stolica Apostolska pomijała te sprawy milczeniem zarówno w bulli Militantis Ecclesiae z 12 III 1818 r., jak też w Ex imposita nobis z 30 VI 1818 r. ${ }^{11}$ Mimo tych faktów Stolica Apostolska była formalnie nieustępliwa. Po krwawym zgnieceniu powstania listopadowego przez Rosję (1831), nadany Królestwu Polskiemu przez cara Mikołaja I Statut organiczny (26 II 1832), po uchyleniu konstytucji z 1815 r. głosił, że nominacja arcybiskupa i biskupów będzie nadal należała do cara, ale pewien wpływ na dobór kandydatów przyznawał namiestnikowi i radzie stanu Królestwa. Odtąd Rada administracyjna „miała obierać i przedstawiać carowi przez namiestnika Królestwa kandydatów na wakujące miejsca arcybiskupów i biskupów" (art 26) ${ }^{12}$. Faktycznie car posiadał pełne prawa mianowania kandydatów na wszystkie biskupstwa w Królestwie Polskim, ograniczone tylko przez Stolicę Swiętą, która dzięki prekonizacji mogła kandydatów zatwierdzić, względnie odrzucić.

W pertraktacjach o konkordat strona rosyjska postawiła problem w $1846 \mathrm{r}$. i zażądała, aby „nominacja biskupów w Cesarstwie i Królestwie Polskim nale-

${ }^{9}$ Dziennik praw Królestwa Polskiego, t. 1 (b.m.r.w.), nr 1 s. 34; Konstytucje polskie 17911921, wyd. M. Handels m a n, Warszawa 1922, s. 51 (art. 42).

${ }^{10} \mathrm{~S}$. Olszamowska-S kowrońsk a, La correspondance..., nr 8 s. 205-210.

${ }^{11}$ Akty i gramoty..., s. $137-177$.

${ }^{12}$ Konstytucje polskie..., s. 101, 103. 
żały do cesarza, a instytucja do Stolicy Swiętej"13. Postulat ten został zamieszczony w artykule 12 konkordatu z Rosją (1847), ale z zaznaczeniem, że w każdym wypadku obsadzanie stolicy biskupiej będzie miało miejsce za uprzednim porozumieniem obydwóch stron ${ }^{14}$. I to prawo obowiązywało do $1917 \mathrm{r}$. W Królestwie Polskim po 1861 r. pewien wpływ na dobór kandydatów na biskupstwa miała Rada Duchowna przy Komisji Rządowej WR i OP, której przewodniczył sam metropolita warszawski.

W Królestwie Polskim w 1818 r. zniesiono 2 diecezje (Kielce, Wigry) i stworzono 3 nowe (Sandomierz, Janów Podlaski, Sejny). W ramach represji po powstaniu styczniowym (1863) władze carskie samowolnie zlikwidowały diecezję w Janowie Podlaskim (1866); w r. 1882 wznowiono diecezję kielecką. Było więc 8 diecezji. I tu stolice biskupie dostawały się często ludziom starym, lojalnym wobec zaborcy i słabym. Problem ten prezentuje tabela $\mathrm{nr} 2^{15}$.

Tab. 2: Wiek biskupów nominatów w Królestwie Polskim 1818-1900

\begin{tabular}{|l|l|ccccc|c|}
\hline Lp. & Diecezja & \multicolumn{5}{|c|}{ Do roku życia } & Razem \\
& & 50. & 60. & 70. & 75. & 80. & \\
\hline 1. & Warszawa & 1 & 1 & 2 & 1 & 4 & 9 \\
2. & Kraków-Kielce & 1 & 1 & 2 & - & - & 4 \\
3. & Janów Podlaski & 1 & - & 2 & $(1866$ zniesiona $)$ & 3 \\
4. & Lublin & - & 2 & 3 & - & 1 & 6 \\
5. & Plock & 3 & 2 & - & - & 1 & 6 \\
6. & Sandomierz & - & - & 2 & - & 2 & 4 \\
7. & Sejny & 1 & 1 & 3 & 1 & - & 6 \\
8. & Wlocławek & 2 & 4 & 2 & - & - & 8 \\
\hline Łącznie & 9 & 11 & 16 & 2 & 8 & 46 \\
\hline
\end{tabular}

Tylko 19,57\% biskupów w Królestwie Połskim objęło stolice biskupie do 50 roku życia, $23,91 \%$ do 60 roku życia, $34,78 \%$ do 70 roku życia i $4,35 \%$ do 75 roku życia, oraz $17,39 \%$ w latach $76-82$ życia. Przeciętny wiek nominata w Królestwie Polskim wynosił 65 lat.

Przy takiej selekcji kandydatów tylko przez pomyłkę władz rosyjskich mógł dojść do stolicy biskupiej kandydat o walorach nieprzeciętnych z punktu widzenia wymogów prawa kościelnego i potrzeb rusyfikowanego przemocą i administracyjnie Narodu polskiego. Nic dziwnego, że wśród biskupów Cesarstwa Rosyjskiego i Królestwa Polskiego spotykamy takich, którzy wierni Rosji, pod jej presją i na jej rozkaz publicznie potępiali powstania narodowe. Tak

\footnotetext{
${ }^{13}$ S. Olszamowsk a-Sk ow rońs k a, Le concordat..., nr 57 s. 737, 783.

${ }^{14}$ B. Ku mor, Ustrój..., s. 64.

${ }^{15}$ R. Ritzler, P. Sefrin, jw., vol. 6 s. 166, 279 n., 310, 333, 344, 399; vol. 7 s. 315, 329, 349 , $460,499,516,594$.
} 
potępił powstanie listopadowe biskup żmudzki Józef Giedroyć (1831) i metropolita mohylowski Kasper Cieciszowki (1831). Po powstaniu styczniowym podobnie postąpił biskup sejneński Konstanty Łubieński (1863) ${ }^{16}$. O podobnej postawie byli administrator archidiecezji mohylowskiej biskup J. S. Staniewski i narzucony przez carat administrator diecezji wileńskiej ks. Piotr Żyliński. Na rozkaz władców rosyjskich wprowadzali oni w latach 1869-1870 język rosyjski do nabożeństw, kazań i katechizacji w kościołach polskich ${ }^{17}$. Wiadomo, że tacy hierarchowie nie wiele mogli zrobić na polu duszpasterskim, a przepaść narodowa między nimi a wiernymi stała się przysłowiowym murem chińskim między pasterzami a ich owieczkami.

Inną formą polityki rosyjskiej w stosunku do obsady biskupstw na dawnych ziemiach polskich były deportacje. W wypadku pomyłki władz, kiedy kandydat okazał się wiernym zarówno w stosunku do swego narodu, jak i obrońcą praw ograniczanego wciąż Kościoła, stosowały one inną formę nacisków i represji: deportacje w głąb Rosji lub na Syberię. Te drastyczne formy represji zastosowała carska Rosja wobec biskupów polskich jeszcze w XVIII wieku. Dotyczyły one biskupów przeciwnych interwencyjnej polityce Rosji w Polsce w okresie królów z rodziny Sasów, Wettinów. Tak w 1708 r. wojska rosyjskie uwięziły w Polsce metropolitę lwowskiego ob. łac. Konstantego Zielińskiego, a następnie wywiozły go do Moskwy, gdzie arcybiskup zmarł w 1710 r. Arcybiskup Zieliński był zwolennikiem króla Stanisława Leszczyńskiego, którego zwalczała Rosja ${ }^{18}$. W dniu 14 V 1767 r. ambasador rosyjski Repnin wywiózł na zesłanie do Kaługi biskupa krakowskiego Ignacego Kajetana Sołtyka i biskupa kijowskiego Józefa Andrzeja Załuskiego i dwóch innych senatorów za przeciwstawianie się interwencyjnej polityce religijnej Rosji w Polsce. Zesłani przebywali na wygnaniu do 18 III $1773 \mathrm{r}^{19}$.

W pierwszej połowie XIX stulecia deportacje te były jeszcze rzadkie. W okresie rządów cara Aleksandra I (1801-1825) na zesłaniu w Bujniczach na Białorusi przebywal metropolita mohylowski St. B. Siestrzeńcewicz (18001801), a biskup miński Jakub Ignacy Dederko w Ołyce na Wołyniu (18161829). Za rządów cara Mikołaja I (1825-1855) na zesłanie do Ozieran w Rosji został skazany biskup podlaski Marceli Gutkowski (1840), a do Opawy na Śląsku Czeskim biskup krakowski Karol Skórkowski (1835). Obydwie deportacje miały charakter polityczny i religijny ${ }^{20}$.

Deportacje te uwielokrotniły się w drugiej połowie XIX wieku. I tak w ra-

${ }^{16} \mathrm{H}$. D y lą gow a, Duchowieństwo katolickie wobec sprawy narodowej (1764-1864), Lublin 1981 , s. 86-91, 126-138.

${ }_{17}$ A. Boudou, jw., t. 2 s. 412 nn.

${ }^{18}$ S. Szy dels k i, Konstanty Zieliński arcybiskup lwowski, Kraków 1910, s. 104 nn.

${ }^{19}$ L. Hajd u ki ew icz, Historia nauki polskiej, t. 6, Wrocław 1974, s. 633-634, 775-777.

${ }^{20}$ Nowy Korbut. Oswiecenie, opr. E. A le k s a nd row s k a i in., t. 6/2, Warszawa 1970, s. 170; A. Boudou, jw., t. 1 s. 222 n., 266 nn.; A. Godlew ski, Jakub Dederko, [w:] Polski stownik biograficzny, t. 5, Kraków 1939-1946, s. 47-48. 
mach represji po powstaniu styczniowym (1863) i na tle wprowadzania języka rosyjskiego do nabożeństw dodatkowych (1869) deportowano aż 9 biskupów w głąb Rosji; byli to: biskup wileński Adam Stanisław Krasiński (1863 - Wiatka), biskup miński Adam Wojtkiewicz (1869 - Wilno), biskup kamieniecki Antoni Fijałkowski (1866 - Symferopol na Krymie), biskup łucko-żytomierski Kasper Borowski (1869 - Perm). Byli to biskupi z metropolii mohylowskiej. Podobną dewastację w szeregach episkopatu przeprowadziły władze rosyjskie w Królestwie Polskim. I tu deportacje miały charakter religijno-narodowy w ramach represji po powstaniu styczniowym $\mathrm{i}$ likwidacji resztek autonomii Kościoła w Królestwie Polskim. Tak w latach 1863 - 1869 zostali deportowani: metropolita warszawski Zygmunt Szczęsny Feliński (1863 - Jarosław nad Wołgą), biskup chełmski gr. kat. Jan Kaliński (1866 - Wiatka), biskup płocki Wincenty Chościak Popiel (1869- Niżny Nowogród), biskup sejneński Konstanty Łubieński (1869 - Niżny Nowogród) oraz biskup podlaski Beniamin Szymański (1866 — Łomża $)^{21}$.

Ta polityka dziesiątkowania episkopatu polskiego przybrała tak wielkie rozmiary, że w roku zwołania I Soboru Watykańskiego (1869) na 2 metropolie i 15 diecezji pod zaborem rosyjskim, obydwie metropolie i 10 diecezji wakowało już to na skutek śmierci, już to na skutek deportacji biskupów. Najbardziej bodaj nieszczęśliwa była wileńska stolica biskupia, której ordynariusze w latach 1860-1918 z wyjątkiem biskupa A.F. Audziewicza (1890-1894), wszyscy byli deportowani w głąb Rosji za przeciwstawianie się władzom rosyjskim posyłania dzieci polskich i katolickich do rosyjskich szków cerkiewnych. Tak po biskupie Krasińskim (1863) został wywieziony do Jarosławia nad Wołgą biskup Karol Hryniewiecki (1885), do Tweru biskup Stefan A. Zwierowicz (1901) i do Petersburga biskup wileński Edward Ropp (1907)22. W 1909 r. na wygnanie został skazany biskup żmudzki Kasper F. Cyrtowt i w 1911 r. biskup pomocniczy mohylowski Stefan Denisewicz; ten ostatni za utworzenie Sodalicji Mariańskiej23. Ten obraz nienormalnej sytuacji Kościoła pod berłem carów pogarszał drastycznie fakt, że na 24 stanowiska biskupów pomocniczych w diecezjach Cesarstwa Rosyjskiego i Królestwa Polskiego aż 21 było wakujących, z czego biskup pomocniczy warszawski Paweł Rzewuski został deportowany do Astrachania nad Morzem Kaspijskim (1864), a biskup pomocniczy żmudzki Kazimierz Bareśniewicz do Mitawy na Łotwie (1869/70). Tę bolesną sytuację Kościoła katolickiego pod berłem carów dobrze scharakteryzował o. Tomasz Żółtek OP z Petersburga w poufnym liście do O. Wincentego Jandala, generała zakonu dominikanów w Rzymie z dnia 17 XII 1869 r. ${ }^{24}$ :

${ }^{21}$ B. K u mor, Udział biskupów polskich w I Soborze Watykańskim, „Analecta Cracoviensia". T. 2: 1970 s. 412 nn.; A. B ou dou, jw., t. 2 s. 253 nn.

22 J. Ku rcze wski, Biskupstwo wileńskie, Wilno 1912 s. 72-75.

${ }^{23} \mathrm{~J}$. S ch midli n, Papstgeschichte der neuesten Zeit, Bd 3, München 1936, s. 126.

${ }^{24} \mathrm{Z}$. Ol s z a m ow s k a-S k ow rońs ka, Tentatives d'introduire la langue Russe dans les églises latins de la Pologne Orientale (1865-1903), „Antemurale” 11:1967 nr 11 s. 91-95. 
Trzy diecezje (Kamieniec Podolski, Janów Podlaski, Mińsk) zostały w sposób bezprawny zniesione, dwie dalsze (Plock, Augustów - Sejny) prawdopodobnie w najbliższym czasie ulegną temu samemu losowi, biskupi częściowo pozbawieni swoich stolic biskupich (A. Fijalkowski, A. Wojtkiewicz, B. Szymański), lub deportowani na wygnanie (Z.F. Feliński, A.S. Krasiński, K. Borowski, J. Kaliński, W. Popiel, K. Łubieński). Na ich miejsce wbrew wszelkim przepisom prawa kanonicznego narzucono intruzów, którzy jako administratorzy gotowi są przyjąć i wykonać każdy rozkaz rządu, nawet najbardziej szkodliwy dla religii katolickiej.

W takiej sytuacji biskupi polscy zaboru rosyjskiego nie mogli pojawić się na I soborze watykańskim w Rzymie.

W celu wywarcia większego nacisku na Rzym przy nominacjach biskupów carat stosował trzecią formę polityki kościelnej w tym zakresie, były to przedłużające się wakanse stolic biskupich. Sobór trydencki w dekrecie Capitulum sede vacante $\mathrm{z}$ dnia 11 XI 1563 r. zobowiązał kapitułę, by w ciągu 8 dni od śmierci biskupa wybrała wikariusza kapitulnego. Kandydat na wikariat kapitulny winien mieć ukończone przynajmniej 25 lat życia i posiadać stopień licencjata, albo doktora prawa kanonicznego, lub przynajmniej odpowiednią wiedzę i praktykę ${ }^{25}$. Te właśnie przepisy kanoniczne wykorzystywał rząd rosyjski i poprzez różne szykany i manipulacje narzucał kapitułom własnych, najczęściej starych, chorowitych i bojaźliwych kandydatów na wikariuszów kapitulnych.

Polityka przedłużających się wakansów na stolicach biskupich w Cesarstwie Rosyjskim już za cara Mikołaja I doprowadziła do tego, że od 1842 r. był tu tylko jeden biskup ordynariusz na 6 diecezji. Był nim biskup łucki i żytomierski Michał Piwnicki ( $\nmid 29$ V 1845), a kiedy i on zmarł, pozostał tylko 1 biskup pomocniczy Kazimierz Dmochowski w Wilnie. Był to więc niezwykle dramatyczny problem. Kto miał udzielać święceń kapłańskich dla tego lokalnego Kościoła w metropolii mohylowskiej, który około 1850 r. liczył około 3 miliony wiernych? Sytuacja stawała się ostrzejsza na skutek olbrzymich przestrzeni i prymitywnej komunikacji. Sytuacja ta miała się zmienić dopiero w 1848 r. Podobna sytuacja powtórzyła się w 1872 r., kiedy znów w całym Cesarstwie Rosyjskim urzędował tylko jeden biskup ordynariusz w Konwie na Litwie (Maciej Wołonczewski), a w pozostałych czterech diecezjach wikariusze kapitulni. Dwóch z nich: administratora archidiecezji mohylowskiej, biskupa pomocniczego J.M. Staniewskiego i administratora diecezji wileńskiej ks. Piotra Żylińskiego Stolica Apostolska obłożyła ekskomuniką za uzurpowanie sobie urzędu administratora diecezji i za wprowadzanie języka rosyjskiego do nabożeństw, kazań i katechezy ${ }^{26}$.

Ze względu na machinacje władzy świeckiej, zwłaszcza w zaborze rosyjskim, pap. Pius IX w konstytucji apostolskiej Romanus Pontifex z dnia 28 VIII

${ }^{25}$ Concilii Tridentini [...] canones et decreta, cura G. Smets, Bielefeld 1858, s. 117 (De reform, cap. 3).

${ }^{26}$ A. B oudou, jw., t. 2 s. 558 nn. 
1873 r. postanowił, że w chwili wakansu stolicy biskupiej cała jurysdykcja przechodzi na wikariusza kapitulnego prawnie obranego, że kapituła nic z niej nie może dla siebie zatrzymać, ani też nie wolno jej wybierać wikariusza na pewien określony czas, a tym bardziej nie może go usunąć. Wybrany ważnie wikariusz kapitulny pozostaje na urzędzie dotąd, dokąd nie zostanie mianowany przez Stolicę Apostolską biskup i nie złoży kapitule pisma papieskiego. Papież zabronił surowo kapitułom wyboru tych kandydatów, których na to stanowisko mianowała władza świecka ${ }^{27}$.

Przypatrzmy się teraz jak wyglądały wakanse stolic biskupich pod berłem carów rosyjskich tak w metropolii mohylowskiej, jak też i w metropolii warszawskiej w latach 1815-1918 28 .

Tab. 3: Wakanse stolic biskupich w metropolii mohylowskiej

\begin{tabular}{|c|l|c|c|}
\hline Lp. & Diecezja & \multicolumn{1}{|c|}{ Lata wakansu } & Razem \\
\hline L. & Mohylów & $1826-1827,1831-1840,1842-1848$, & \\
& & $1855-1856,1863-1872,1889-1891$, & \\
& & $1899-1901,1905-1908,1909-1910$, & \\
2. & Kamieniec Podolski & $1914-1917$ & 37 \\
3. & Luck-Żytomierz & $1842-1853,1855-1860(1866$ zniesiona $)$ & 16 \\
& & $1845-1848,1870-1883,1891-1897$, & \\
4. & Mińsk & $1898-1897,1911-1916$ & 28 \\
5. & Tyraspol & $1816-1825,1839-1852(1869$ zniesiona $)$ & 9 \\
6. & Wilno & $1864-1872,1903-1904$ & \\
& & $1815-1840,1841-1848,1856-1858$, & 72 \\
7. & Żmudź & $1863-1883,1885-1889,1895-1897$, & 22 \\
& & $1902-1903,1907-1918$ & \\
\hline
\end{tabular}

Na przestrzeni 103 lat wakanse na 7 stolicach biskupich w Cesarstwie Rosyjskim wynosiły łącznie 212 lat, co znaczyło, że przeciętny wakans stolicy biskupiej w tym okresie wynosił 31 lat. Najdłużej nie posiadała ordynariusza diecezja wileńska (72 lata) i archidiecezja mohylowska (37 lat). Tylko diecezja tyraspolska na przestrzeni 70 lat istnienia wakowała 9 lat lącznie $(12,88 \%)$. W omawianym okresie diecezja wileńska miała aż 16 administratorów, a tylko 7 biskupów ordynariuszów ${ }^{29}$.

${ }^{27}$ B. Ku mor, Ustrój s. 270.

${ }^{28} \mathrm{~K}$. Dola, Katalog arcybiskupów $i$ biskupów rezydencjalnych metropolii $i$ diecezji polskich obrzqdku tacińskiego do czasów wspótczesnych, [w:] Historia Kościoła w Polsce, t. 2/2, Poznań 1979 s. 256-301

${ }^{29}$ Catalogus ecclesiarum et cleri archidioecesani Vilnensis pro anno Domini 1929, Vilnae 1929, s. 158-160; J. Kurczewski, jw., s. 64-75. 
Nie lżejsza była sytuacja w tym zakresie w metropolii warszawskiej w byłym Królestwie Polskim. I tu rządy carów stosowały podobne metody przy obsadzaniu stolic biskupich i one wakowały przez długie lata. Problem ten ilustruje tabela $\mathrm{nr} 4^{30}$.

Tab. 4: Wakanse stolic biskupich w metropolii warszawskiej

\begin{tabular}{|cl|c|c|}
\hline Lp. & Diecezja & Lata wakansu & $\begin{array}{c}\text { Razem } \\
\text { lat }\end{array}$ \\
\hline 1. & Warszawa & $1823-1824,1827-1828,1829-1836$, & \\
& & $1838-1856,1863-1883,1912-1913$ & 48 \\
2. & Augustów Sejny & $1823-1825,1834-1836,1847-1863$, & \\
& & $1869-1872,1893-1897,1902-1910$ & 35 \\
3. & Janów Podlaski & $1825-1826,1840-1856(1866$ zniesiona) & 17 \\
4. & Kraków-Kielce & $1828-1829,1835-1883,1907-1910$ & 53 \\
5. & Lublin & $1824-1825,1839-1852,1863-1871$ & \\
& & $1879-1883,1885-1889,1914-1918$ & 34 \\
6. & Płock & $1852-1863,1869-1883,1885-1889$, & 35 \\
7. & Sandomierz & $1896-1901,1903-1904$ & \\
& & $1830-1840,1852-1859,1880-1883$, & 23 \\
8. & Włocławek & $1901-1902,1908-1910$ & 19 \\
\hline
\end{tabular}

Łączne wakanse na stolicach biskupich w byłym Królestwie Polskim w latach 1815-1918 trwały 264 lata, przy czym najdłużej trwały one na stolicy metropolitalnej w Warszawie (48 lat) i w biskupstwie Kraków-Kielce (56 lat). Przeciętny wakans stolicy biskupiej trwał zatem 33 lata. Warto tu zauważyć, że na przestrzeni 100 lat Warszawa miał 9 arcybiskupów i aż 16 administratorów ${ }^{31}$. Te przedługie wakanse i tymczasowe administracje dezorganizowały życie religijne, utrudniały jego rozwój i dawały władzy obcej wyznaniowo i narodowo przemożny wpływ na jego bieg.

\section{Zabór pruski}

Zabór pruski w latach 1795-1807 obejmował centralne ziemie polskie ze stolicą prymasów Polski w Gnieźnie i stolicą państwa Warszawą, a jego granice opierały się o bieg rzek Pilica, Wisła, Bug i Niemen, aż do jego ujścia do Morza Bałtyckiego. Granice tego zaboru po kongresie wiedeńskim (1815) zostały zacieśnione do Wielkopolski i Pomorza wraz z Warmią. Znajdowały się tu diecezje: archidiecezja gnieźnieńska, oraz diecezja poznańska, chełmińska, war-

${ }^{30}$ Zob. przypis 28 .

${ }^{31}$ Katalog archidiecezji warszawskiej 1981, Warszawa 1981, s. 51-55. 
mińska i na Sląsku wrocławska. Bulla pap. Piusa VII (16 VII 1821) na wniosek Prus zakreśliła wszystkim diecezjom nowe granice i połączyła unią personalną arcybiskupstwo gnieźnieńskie $\mathrm{z}$ arcybiskupstwem poznańskim. Zaborczy rząd pruski zakazał metropolitom gnieźnieńskim używania tytułu „prymas Polski” (1795) i „pierwszy książę” (1823).

Królowie pruscy uzurpowali sobie jako prawo koronne uprawnienia królów polskich do mianowania biskupów (14 VII 1793). W oparciu o nie król pruski mianował kandydatów na wakujące biskupstwa, przesyłał kapitule katedralnej reskrypt o nominacji i prezencie kandydata i delegował na mające się odbyć wybory kapitulne swego pełnomocnika. Desygnowanego kandydata wybierała kapituła. Była to czcza formalność, gdyż kapituła miała do wyboru tylko jednego kandydata i tego musiała wybrać. Bulle papieskie pomijały zupełnym milczeniem zarówno nominacje królów pruskich, jak też i wybory kapitulne. Od $1821 \mathrm{r}$. podstawy prawne obsadzania stolic biskupich stanowiła bulla De salute animarum (16 VII 1821) - umowa dwustronna między Prusami a Stolicą Apostolską, normująca cały szereg spraw Kościoła katolickiego o charakterze prawno-ustrojowym w Prusach. Ponieważ Rzym odmówił królowi pruskiemu prawa nominacji na stolice biskupie, dlatego wspomniana bulla postanawiała, aby wyboru biskupa dokonywała kapituła katedralna ${ }^{32}$.

W związku z tym przywilejem pap. Piusa VII wydał tego samego dnia brewe Quod de fidelium, w którym podał normy dotyczące wyboru biskupów przez kapituły. Winny one wybierać ,godniejszych i dla Kościoła pożyteczniejszych kandydatów ... i którzy będą do przyjęcia ze strony króla pruskiego (nec Serenissimo regi minus gratos esse noveritis). O tej ostatniej ,zalecie” kapituła winna się upewnić przed przystąpieniem do wyborów. Dawało to niewątpliwie protestanckiej władzy państwowej poważny wpływ na dobór kandydatów. Wreszcie brewe zacieśniało krąg kandydatów do „obywateli Prus”, względnie do Niemców „mieszkających poza granicami Królestwa Pruskiego”, o ile na nich rząd wyrazi zgodę 33 .

W celu wzmocnienia procesów germanizacyjnych na terenach zabranych Polsce rząd pruski obsadzał stolice biskupie z wyjątkiem Gniezna-Poznania wyłącznie Niemcami, ci bowiem byli „osobami najbardziej miłymi” królowi Prus. Tę politykę zainaugurowały Prusy tuż po 1772 r. Przypatrzmy się temu problemowi w opisie tabelarycznym ${ }^{34}$.

${ }^{32}$ B. Ku mor, Ustrój..., s. 139.

33 Tamże, s. 140.

${ }^{34}$ K. Dola, jw., s. $260-261$. 
Tab. 5: Narodowość biskupów diecezji chełmińskiej 1772—1918

\begin{tabular}{|c|l|c|l|}
\hline Lp. & Imię i nazwisko & Lata rządów & Narodowość \\
\hline 1. & Józef K. Hohenzollern & $1778-1795$ & Niemiec \\
2. & Franciszek Rydzyński & $1795-1814$ & Polak \\
3. & Ignacy S. Mathy & $1823-1832$ & Niemiec \\
4. & Anastazy Sedlag & $1833-1856$ & Niemiec \\
5. & Jan N. Marwitz & $1857-1886$ & Niemiec \\
6. & Leon Redner & $1886-1898$ & Niemiec \\
7. & Augustyn Rosentreter & $1898-1926$ & Niemiec \\
\hline
\end{tabular}

Wśród 7 biskupów chełmińskich w latach niewoli narodowej aż 6 było narodowości niemieckiej, mimo że wierni tej diecezji w przytłaczającej większości byli Polakami. Następstwem tego była całkowita germanizacja seminarium duchownego i konsystorza biskupiego, oraz urzędów diecezjalnych, duszpasterstwa, liturgii i katechizacji. Biskupi Niemcy „sprowadzali kapłanów z Niemiec, słabo władających językiem polskim, ich napływ przyczynił się w pewnej mierze do germanizacji diecezji, co było walną pomocą dla rządowego programu kolonizacyjnego"35.

Podobną sytuację stworzyły rządy pruskie w diecezji warmińskiej zabranej Polsce w 1772 r. Od 1795 r. stolica biskupia tej diecezji była wyłącznie w rękach Niemców ${ }^{36}$. Zagadnienie to ilustruje tabela nr 6.

Tab. 6: Narodowość biskupów diecezji warmińskich 1795—1918

\begin{tabular}{|c|l|l|l|}
\hline Lp. & Imię i nazwisko & Lata rządów & Narodowość \\
\hline 1. & J. K. Hohenzollern & $1795-1803$ & Niemiec \\
2. & Józef Hohenzollern & $1817-1836$ & Niemiec \\
3. & Andrzej S. Hatten & $1837-1841$ & Niemiec \\
4. & Józef A. Geritz & $1841-1867$ & Niemiec \\
5. & Filip Krementz & $1867-1885$ & Niemiec \\
6. & Andrzej Thiel & $1885-1908$ & Niemiec \\
7. & Augustyn Bludau & $1908-1930$ & Niemiec \\
\hline
\end{tabular}

Większość biskupów warmińskich nie znała zupełnie języka polskiego, ale przynajmniej do drugiej połowy XIX wieku uznawali oni odrębność narodową i językową Polaków. Zgermanizowali jednak wszystkie instytucje diecezjalne, zwłaszcza seminarium duchowne, kapitułę i konsystorz. Od czasu Kulturkampfu (1871) najczęściej nie dbali o zaspokojenie potrzeb duchowych ludności 107.

35 A. Lie d tke, Zarys dziejów diecezji chetmińskiej, „Nasza Przeszłość” 34:1971, s. 100${ }^{36}$ K. Dola, jw., s. 296. 
polskiej w jej języku ojczystym, nie przeciwstawiali się akcji germanizacyjnej w katechizacji i liturgii kościelnej, faworyzowali mniejszość niemiecką, ograniczali nabożeństwa polskie i solidaryzowali się $\mathrm{z}$ akcją germanizacyjną rządu ${ }^{37}$. Trzeba podkreślić, że wielu duchownych niemieckich nie godziło się z brutalnymi metodami germanizacji, stosowanymi przez władze pruskie.

Specjalną polityką kierował się rząd pruski przy obsadzaniu stolicy prymasów Polskich w Gnieźnie. W latach 1816-1821, a także później władze pruskie pragnęły znieść arcybiskupstwo gnieźnieńskie, a kiedy temu przeciwstawiła się polska opinia publiczna i Rzym papieski, doprowadzily w 1821 r. do połączenia unią personalną Gniezna z Poznaniem. Polityka wobec tej stolicy była polityką narzucania Niemców na tę stolicę, więzienia i deportacji polskich metropolitów, względnie podtrzymywania długich wakansów. W celu uprawiania takiej polityki władze pruskie spowodowały zawieszenie od 1865 r. praw do elekcji obydwóch kapituł w Gnieźnie i Poznaniu.

Już w 1825 r. pojawił się pierwszy kandydat Niemiec na tron prymasów Polski. Był nim biskup chełmiński Ignacy S. Mathy, który nawet 25 VI $1827 \mathrm{r}$. otrzymał wbrew postanowieniom bulli De salute animarum z $1821 \mathrm{r}$. nominację króla Prus na Gniezno-Poznań, ale pogarszający się jego stan zdrowia i inne okoliczności doprowadziły do upadku jego kandydatury (1828). Kandydatura innego Niemca, Augusta Droste-Bischeringa okazała się na razie nie realna ${ }^{38}$. Pierwsze uwięzienie, a następnie deportacja i areszt arcybiskupa Marcina Dunina w Kołobrzegu (1837-1840) miały miejsce na tle zatargu o małżeństwa mieszane wyznaniowo. I one, zgodnie z polityką Prus, miały służyć dogłębnej germanizacji ludności polskiej w Wielkopolsce, skoro król pruski Fryderyk Wilhelm III zadekretował, że wszystkie dzieci z małżeństw protestancko-katolickich, czyli z reguły polsko-niemieckich winny być wychowane w religii augsbursko-ewangelickiej, a temu sprzeciwił się arcybiskup Dunin. To też było jego winą i przestępstwem, a następnie tytułem do uwięzienia, deportacji i osadzenia w areszcie - twierdzy w Kołobrzegu ${ }^{39}$.

Od 1844 r. zaczęły na listach kandydatów pojawiać się systematycznie nazwiska niemieckie, popierane przez czynniki rządowe. Tak w 1844 r. rząd wymienił jako ewentualnego kandydata na stolicę prymasów Polski ks. Walentego Franka, Niemca ze Sląska. W 1865 r. do Gniezna przyszedł kandydat kompromisowy „civis Romanus”, były nuncjusz apostolski w Brukseli, Mieczysław H. Ledóchowski. W okresie wojującego Kulturkampfu został on aresztowany (2 II 1874), uwięziony w Ostrowie Wielkopolskim (1874-1876), a następnie (3 II 1876) deportowany do zaboru austriackiego ${ }^{40}$. W $1886 \mathrm{r}$. po rezygnacji kard.

${ }^{37}$ J. O błą k, Historia diecezji warmińskiej, Olsztyn 1959, s. 124-127.

${ }^{38}$ Z. Grot, Teofil Wolicki, [w:] Na stolicy prymasowskiej w Gnieźnie i Poznaniu, Poznań 1981, s. 108.

${ }^{39}$ M. B a n a z a k, Marcin Dunin 1830 - 1842, [w:] Na stolicy..., s. 156 n.

40 Z. Zi elińs k i, Mieczystaw Ledóchowski 1886-1890,[w:] Na stolicy..., s. $194 \mathrm{nn}$. 
M. Ledóchowskiego Prusy dopięły celu swoich marzeń; na stolicy prymasów Polski zasiadł Niemiec, Juliusz Diner, proboszcz z Królewca w Prusach Wschodnich (1886-1890).

Rzym — pisal „Dziennik Poznański” — godząc się na obsadzenie stanowiska arcybiskupiego archidiecezji gnieźnieńsko-poznańskiej nie uwzględnil do tyla ani uczuć, ani liczbowej przewagi mieszkańców jej, aby sięgnąc dla nich po arcypasterza obcego narodowością... Byłoby obłudą z naszej strony chcieć taić żal serc naszych, iż nowomianowany arcypasterz nie do naszej zalicza się narodowości. Żal, jaki z tego powodu wypowiadają, jest pośród naszej ludności powszechny ${ }^{41}$.

Kandydatury Niemców pojawiły się nadto w 1906 r. (ks. J. Eckaust) ${ }^{42}$. Te też powody decydowały głównie o długoletnich wakansach obydwóch stolic arcybiskupich. W latach 1795-1918 stolica gnieźnieńska i poznańska wakowała łącznie 26 lat, przy czym najdłuższe wakanse przypadły na lata 1801-1806, 1906-1914. W tym ostatnim wypadku rząd pruski nie zamierzał dopuścić Polaka do stolicy metropolitalnej, a kandydatura Niemca tym razem dla Rzymu była nierealną. Sytuację na tym odcinku zmieniła dopiero I wojna światowa, kiedy rząd pruski za cenę pozyskania sobie Polaków zgodził się na kandydaturę Polaka (abp E. Likowski) ${ }^{43}$.

Według urzędowego Schematyzmu diecezji wrocławskiej na Śląsku z 1867 r. diecezja ta w części pruskiej i austriacko-czeskiej liczyła 1712114 katolików, z czego 884781 (51,68\%) mówiło wyłącznie po polsku, a dalsze 94246 $(5,5 \%)$ posługiwało się językiem polskim i niemieckim. Zdecydowana więc mniejszość niemiecka liczyła tylko $733087(42,82 \%)$ katolików ${ }^{44}$. Ta zdecydowana większość katolików mówiących po polsku na Śląsku w XIX wieku, nie mogła nawet marzyć o biskupie narodowości polskiej. Diecezja ta, pozostająca od 1742 r. pod panowaniem Prus, miała 9 biskupów ordynariuszów wyłącznie Niemców i żaden z nich, z wyjątkiem biskupa E. Schimonskyego (1824 1832), nie znał języka polskiego. Postawa germanizacyjna kard. Jerzego Koppa (1887-1914), zalecającego proboszczom w poufnych okólnikach wprowadzenie kazań, katechezy, pieśni i spowiedzi w języku niemieckim (1890), wspomagała ustawiczne zapędy germanizacyjne rządu pruskiego i nie zawsze liczyła się z potrzebami duchowymi katolików polskich w tej diecezji ${ }^{45}$. Fakt, że w latach 1772/95 - 1918 na łączną liczbę 34 nominacji na stolice biskupie tego zaboru aż 23 nominatów $(67,65 \%)$ było Niemcami, ma swoją drastyczną wymowę, podobnie jak fakt, że 3 stolice biskupie dawnych ziem polskich pozostawały wyłącznie w rękach Niemców, oraz że w latach 1886-1890 Niemiec zasiadł na stolicy prymasów Polski.

\footnotetext{
${ }^{41}$ W. R a c zk ow s k i, Juliusz Dinder 1886-1890,[w:] Na stolicy..., s. 230-242.

${ }^{42}$ B. Ku mor, Ustrój..., s. 141.

${ }^{43}$ K. S migiel, Edward Likowski 1914-1915, [w:] N a s tolicy.., s. $274-282$.

44 Schematismus des Bisthums Breslau [...] für das Jahr 1867, Breslau 1867, s. 218 -222.

${ }^{45}$ A. Rog als k i, Kościót katolicki na Slasku, Warszawa 1955, s. 240-249.
} 


\section{Zabór austriacki}

Czasowo problem obsady biskupstw polskich w zaborze austriackim dzieli się wyraźnie na dwa okresy; pierwszy obejmujący lata 1772/95-1855 ma tendencje wyraźnie antypolskie i germanizacyjne i drugi, obejmujący lata 18551918 , to okres autonomii Galicji i okres wyłącznie polskich biskupów w tym kraju. Zajmiemy się więc tu tylko okresem pierwszym.

Już po pierwszym rozbiorze Polski (1772) radca nadworny F.J. Heinke w memoriale z października 1787 r., złożonym na ręce ces. Józefa II, postawił tezę, że cesarz może bez zgody Stolicy Apostolskiej mianować biskupów i przekazywać im urząd kościelny ${ }^{46}$. Taką też zasadę przyjęli cesarze Austrii w zakresie nominacji biskupów. Opór Rzymu łamano faktami dokonanymi, jak to miało miejsce przy obsadzie metropolii w Lublianie $(1787)^{47}$. Prawo nominacji cesarskiej biskupów również w Galicji potwierdził konkordat austriacki (1855), oraz patent ces. Franciszka Józefa I z dnia 7 V 1874 r. Przepisy prawne wymagały od kandydata obywatelstwa austriackiego, odpowiedniej postawy moralnej i obywatelskiej i odpowiednich zdolności do piastowania tego urzędu kościelnego. Kandydatów na stolice biskupie w Galicji wysuwało gubernium austriackie we Lwowie, względnie później Namiestnictwo ${ }^{48}$.

Kościelna polityka Austrii w stosunku do obsady biskupstw polskich w Galicji różniła się zasadniczo od polityki Prus i Rosji w omawianym zakresie. Ale było to uzasadnione. Austria była monarchią katolicką. Wszak wakanse stolicy metropolitalnej we Lwowie trwały w sumie tylko 11 lat, podczas gdy wakanse Warszawy czy Mohylowa przedłużały się od 37 do 48 lat. Zgodnie z zasadami konserwatyzmu i wzrostem tendencji unifikacyjnych i germanizatorskich w różnonarodowym Cesarstwie Austriackim, rząd popierał wydatnie Niemców i zniemczonych Czechów. Dotyczyło to zarówno obsady najwyższych urzędów konsystorskich, rektoratów w seminariach duchownych, probostw itp. Taki system polityki kościelnej Wiednia trwał od $1848 \mathrm{r}$ i załamał się gwałtownie w czasie Wiosny Ludów $(1848)^{49}$. Przypatrzmy się konkretnie temu problemowi w opisie tabelarycznym.

${ }^{46}$ B. Ku mor, Ustrój..., s. 91.

${ }^{47}$ R. Ritzler, P. Sefrin, jw., vol. 6 s. 227; W. Ch ot kow ski, Historia polityczna Kościota w Galicji za rządów Marii Teresy, t. 2 Kraków 1909 s. 474-501.

${ }^{48}$ B. Ku mor, Ustrój..., s. 91.

${ }^{49}$ Tamże, s. 92. 
Tab. 7: Narodowość biskupów w Galicji ob. lac. 1772—1855

\begin{tabular}{|l|l|ccccc|c|}
\hline Lp. & Diecezja & Polak & Niemiec & Węgier & Ormianin & Czech & Razem \\
\hline 1. & Lwów & 3 & 2 & - & - & 3 & 8 \\
2. & Przemyśl & 3 & - & 1 & 1 & 1 & 6 \\
3. & Tarnów & 2 & 2 & - & 1 & 2 & 7 \\
\hline \multicolumn{2}{l}{ Łącznie } & 8 & 4 & 1 & 2 & 6 & 21 \\
\hline
\end{tabular}

Na łączną liczbę 21 nominacji na stolice biskupie w Galicji, tylko 8 nominatów było Polakami $(38,10 \%), 6$ było zgermanizowanymi Czechami $(28,57 \%), 4$ Niemcami (19,05\%), 2 Ormianami (9,52\%), i 1 Węgrem (4,76\%). Rzecz znamienna, że takiej polityki narodowościowej przy obsadzie stolic biskupich grecko-katolickich nie prowadziła Austria, mimo iż hierarchia tego obrządku istniała w granicach Cesarstwa Austriackiego na Rusi Zakarpackiej, Słowacji i w Siedmiogrodzie. Kler tych diecezji mógł więc dostarczyć kandydatów na grecko-katolickie biskupstwa w Galicji. Bardziej szczegółowo prezentuje ten problem tabela $\mathrm{nr} 8^{50}$.

Tab. 8: Narodowość biskupów Galicji ob. lac. 1772-1855

\begin{tabular}{|c|c|c|c|c|}
\hline Lp. & Diecezja & Imię i nazwisko & Narodowość & Lata rządów \\
\hline 1. & Lwów & K.I.Kicki & Polak & $1797-1812$ \\
\hline 2. & " & W.L.Chlumczansky & Czech & 1813 \\
\hline 3. & $"$ & K. Boul-Schauenstein & Niemiec & $1813-1814$ \\
\hline 4. & ” & A.A Ankwicz & Polak & $1814-1833$ \\
\hline 5. & $"$ & F.X. Luschin & Niemiec & $1834-1835$ \\
\hline 6. & " & F. Pisztek & Czech & $1836-1846$ \\
\hline 7. & ” & W.W. Wacławiczek & Czech & $1847-1848$ \\
\hline 8. & ” & Ł. Baraniecki & Polak & $1849-1858$ \\
\hline 9. & Przemyśl & A.W. Betański & Czech & $1783-1786$ \\
\hline 10. & $"$ & A. Gołaszewski & Polak & $1786-1824$ \\
\hline 11. & $"$ & A. Potoczky & Węgier & $1825-1832$ \\
\hline 12. & " & M. Korczyński & Polak & $1834-1839$ \\
\hline 13. & $"$ & F.A. Zachariasiewicz & Ormianin & $1840-1845$ \\
\hline 14. & $"$ & F.X. Wierzchlejski & Polak & $1846-1860$ \\
\hline 15. & Tarnów & F.A. Janowski & Polak & $1786-1801$ \\
\hline 16. & $"$ & G.T. Ziegler & Niemiec & $1822-1827$ \\
\hline 17. & " & F.M. Chotek & Czech & 1831 \\
\hline 18. & " & F. Pisztek & Czech & $1831-1836$ \\
\hline 19. & $"$ & F.A. Zachariasiewicz & Ormianin & $1836-1840$ \\
\hline 20. & " & J.G. Wojtarowicz & Polak & $1840-1850$ \\
\hline 21. & " & J.A. Pukalski & Ślązak & $1852-1885$ \\
\hline
\end{tabular}

50 B. Ku mor, Obsada metropolii lwowskiej obrzqdku tacińskiego w latach 1772-1918, „Analecta Cracoviensia” 9:1977 s. 447-461; tenże, Obsada biskupstwa tarnowskiego w latach 1783-1807, „Analecta Cracoviensia” 13:1981 s. 425-442. 
Skutki takiej polityki kościelnej były wręcz opłakane. Pasterza od owieczek dzielił mur chiński pochodzenia narodowego i innego, niezrozumiałego języka. Nawet gorliwy biskup G.T. Ziegler pisal na ten temat do pap. Leona XII w dniu 5 XII 1826 r.: „Słowo Boże z wielką radością duszy głoszę tak często, jak tylko mogę po łacinie, lub po niemiecku, jako że na nieszczęście nie znam języka polskiego, którym posługuje się lud w tej diecezji" 51 . Jakie więc mogły być skutki tych kazań, homilii i przemówień biskupa, których lud nic nie rozumiał? W ślad za biskupami Niemcami, czy zniemczonymi Czechami przybywali do Galicji z innych krajów austriackich klerycy i księża. Tylko w latach 1821-1834 przyjęto do diecezji tarnowskiej 131 księży i 77 alumnów, którzy znali najczęściej obok języka niemieckiego jeszcze język czeski ${ }^{52}$. Rola tedy niemieckiego i zniemczonego czeskiego kleru w germnanizacji Galicji musiała być znaczna i szła w parze z kolonizacją niemiecką w tym kraju, prowadzoną przez cesarzy austriackich.

Każdy zaborca uprawiał politykę rusyfikacyjną i germanizacyjną Narodu polskiego i każdy z nich do polityki tej wciągał również Kościół katolicki. Jaką postawę wobec tego problemu zajął Rzym papieski? Jest to osobny problem, ale już tu można powiedzieć, że była ona w większości lojalna wobec rządów zaborczych.

\section{DIE BESETZUNG DER KATHOLISCHEN BISTÜMER DES RÖMISCHEN RITUS IN POLEN IN DER ZEIT VON 1795 BIS 1918}

\section{Zusammenfassung}

Wenn es um die Besetzung der katholischen Bistümer in russischen Anteil des polnischen Gebites ging, dann wandte der Zar seine Vorrechte nutzend, drei Verfahrensweisen an: In Regel ernannte er für diese Ämter Männer, von denen er Ergebenheit erwarten konnte, die in nationalen Angelegenheiten sehr schwankend und auch nicht immer den Grundsätzen der Kirche treu waren. Eine andere Form der russischen Politik in Bezug auf die Besetzung der Bistümer in ehemalig polnischen Gebiet waren Deportationen. Hatten sich die Behörden jedoch geirrt und stellte sich der Kandidat als treuer Verfechter der Interessen seines eigenen Volkes und der Rechte der ständig eingeschränkten Kirche heraus, dann griff man nach anderen Druckmitteln: Man deportierte sie ins Innere Russlands oder nach Sibirien. Bei den Nomination der Bischöfe übte man grösseren Druck auf Rom aus durch ausgedehnte Vakanzen der Bischofsstühle.

Die Könige von Preussen beanspruchten die Befugnis der polnischen Könige, Bischöfe zu ernennen, unrechtmäßigerweise ihr Kronrecht. Seit 1821 bildete die rechtliche Grundlage für die Besetzung der Bischofsitze die Bulle De salute animarum (16. 07. 1821). Um den Germanisie-

${ }^{51}$ Relacje o stanie diecezji tarnowskiej z lat 1791-1863, wyd. B. Ku m o r, Lublin 1977, s. 32. s. 510 .

52 B. Ku mor, Diecezja Tarnowska. Dzieje ustroju i organizacji 1786-1985, Kraków 1985, 
rungsprozess in den erworbenen Gebieten zu verstärken, besetzte die preussische Regierung die Kathedra von Gnesen-Posen ausschließlich mit Deutschen. Diese Politik leiteten Preussen gleich nach 1772 ein.

In österreichischen Anteil am polnischen Gebiet sind zwei Abschnitte der Kirchenpolitik zu unterscheiden: Die Zeit von 1772/95 bis 1855 zeigt deutliche Tendenzen zu polenfeindlicher Germanisierungspolitik. Hingegen 1855-1918 ist die Zeit der Autonomie Galiziens. Die Kathedren waren ausschleßlich mit polnischen Bischöfen besetzt. In Einklang mit den Grundsätzen des Konservatismus und zunehmender Germanisierungstendenzen im multinationalen österreichischen Kaiserreich förderte die Regierung in vor allem Deutsche und eingedeutschte Tschechen. Das gilt sowohl für die Besetzung der höchsten Kirchenämter, wie auch der Domkapitel, der Konsistorialämter, der Rektorate in Priesterseminaren, der Pfarrämter und anderer Stellen. Dieses System der Kirchenpolitik Wiens dauerte bis 1848 . 